\title{
Nationalisme og lokalt tilhørsforhold \\ - køn, klasse og etnicitet som grænsemarkører
}

\section{Af Ann-Dorte Christensen}

Hvad har engelsk cricket, den amerikanske nationalsang og en burkakladt dommer til falles? De er på bver sin måde starke symbolske markeringer af nationale fallesskaber, der $i$ konstruktionen af et ' $v i$ ' samtidig ekskludever 'de andre'. Etnicitet er $i$ disse air den mest markante markor af tilhørsforbold. Men den er tat sammenvavet med baide kon og klasse $i$ saivel underliggende forestillinger som i hverdagslivets sociale relationer.

\section{E S S A Y}

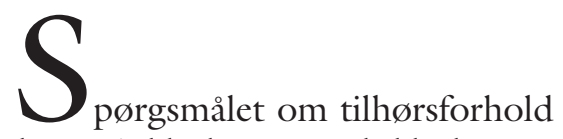
- hvem der er inkluderet og ekskluderet har været et centralt spørgsmål i moderne demokratier - ikke mindst de seneste år i kraft af stigende globalisering og multikulturalisme. Dette skyldes ikke kun, at den største demokratiske udfordring i dag er knyttet til inklusion af etniske minoriteter, men også at tilhørsforhold er blevet en af de dominerende diskurser i den offentlige debat. Stærke markeringer af 'os/dem' definerer såvel gamle som nye fællesskaber samtidig med, at bestemte grupper defineres som 'uden for' disse frllesskaber (Andreassen 2005, Siim 2007).

Der er ingen tvivl om, at etnicitet i dag er den mest synlige markør af tilhørsforhold, men samtidig konstrueres skarpe argumenter og underliggende forestillinger om etnicitet i et tæt samspil med andre kategorier, f.eks. køn og seksualitet. Rikke Andreassen har vist, hvordan kønnet spiller en afgørende rolle i mediernes konstruktion af stereotype opfattelser af etniske mi- 
noriteter. Her konstrueres undertrykte indvandrerkvinder i modsætning til dels aggressive indvandrermænd og dels ligestillede etnisk danske kvinder (Andreassen 2007). Ligeledes viser Camilla Elgs analyse af 'setheds-praksisser', hvordan billedet af den tilslørede krop både fremmedgøres og seksualiseres i det offentlige rum i modsætning til etnisk danske normer om afklædthed, der fremstår som tegn på sundhed og frihed (Elg 2005).

Første del af dette essay præsenterer begrebet tilhørsforhold som 'belonging'. I I forbindelse hermed diskuteres forestillede fællesskaber bl.a. gennem de bidrag, som Nira Yuval-Davis og Judith Butler har udviklet om nationalisme som et forestillet og mono-lingvistisk frllesskab. Disse pointer illustreres gennem et aktuelt eksempel på, hvordan konstruktion af 'danskhed' bruges til at ekskludere 'de andre'. Essayets anden del er baseret på resultater fra INTERLOC-projektet om køn, klasse og etnicitet i Aalborg. På baggrund af narrative interviews analyseres, hvordan tilhørsforhold og identifikation kommer til udtryk i 'almindelige menneskers' fortællinger om deres hverdag.

\section{TILHøRSFORHOLD - ANALYSENIVEAUER} Grundlæggende kan forståelser af tilhørsforhold lokaliseres på tre niveauer:

- tilslutning til større 'forestillede' fallesskaber. De typiske eksempler er nationalisme eller religion, som ofte er forbundet med stærke følelser af fællesskaber. Men sådanne fællesskaber har ofte en bagside, fordi de gennem markeringer af det stærke 'vi' samtidig ekskluderer 'de andre.' Derfor er forestillede fællesskaber et vigtigt led i konstruktionen af os/dem. (Andersson 2001, Yuval-Davis 1997, Butler \& Spivak 2007, Siim 2007, Andreassen 2005).

- tilknytning til kollektive fallesskaber, som f.eks. politiske partier eller sociale bevægel- ser. Der kan være tale om konkret tilknytning til en kollektiv organisering, hvor man mødes og samarbejder. Men der kan også være tale om følelser af tilhørsforhold, f.eks. til arbejderbevægelsen eller kvindebevægelsen (Tilly 2002, Gundelach 1988, Torpe \& Kjeldgaard 2003, Henriksen, se f.eks. Bundesen m.fl. 2001).

- som levet liv, hvor tilhørsforhold er forankret i hverdagslivet. Her handler det om følelser af tilknytning, f.eks. til grupper eller lokale fællesskaber. Disse er ofte baseret på sociale grænsedragninger i forhold til, hvem man identificerer sig med. Sådanne tilhørsforhold kan være refleksive og tilvalgte, men de kan også være underliggende forestillinger i den måde, vi omgås hinanden på i hverdagslivet (Savage 2005, Skeggs 1997, Gullestad 2006, Staunæs 2003, Prieur, 2004, Jørgensen og Mølholt 2007).

I det følgende vil jeg især beskæftige mig med pkt. a og c, da spørgsmålet om forestillede fællesskaber knytter an til spørgsmålet om nationalisme, og spørgsmålet om levet liv relaterer sig til fortællingerne om tilhørsforhold fra Aalborg Øst.

\section{NATIONEN SOM ET FORESTILLET FÆLLESSKAB}

Tankegangen om nationen/nationalstaten som et forestillet fællesskab stammer fra den amerikanske forsker i internationale studier Benedict Anderson. ${ }^{2}$ Han definerer forestillede fællesskaber på følgende måde:

Den [nationen] er et forestillet politisk fællesskab - og forestillet som både uafvxgerligt afgrænset og suveræn. Den er forestillet, fordi medlemmerne af selv den mindste nation aldrig vil kende deres fæller, møde dem eller endsige høre om dem. Alligevel findes i tankerne hos hver enkelt billedet af deres fællesskab (Anderson 2001:48).

Pointen er, at man er en del af et frllesskab, 
der ikke er opbygget omkring konkrete sociale relationer. Alligevel opfattes medlemskab af en nation som 'naturlig' og ikke tilvalgt - som i en familie, hvor man kan ofre sig for staten, og hvor man kan blive dræbt, som vi ser det for øjeblikket i forhold til soldaterne i Irak og i Afghanistan. Selv om sådanne fællesskaber er forestillede har de stor betydning for de opfattelser og konstruktioner, vi skaber om 'os' og 'dem'/'de andre'.

Det er en grundlæggende pointe hos den engelske sociolog og kønsforsker Nira Yuval-Davis, at 'belonging' er både positiv og negativ. Hun skelner mellem på den ene side 'politics of belonging' som primært er negativt og en markering af, hvem der er 'inde' og hvem der er 'ude' af frllesskaber og på den anden side 'feelings of belonging', som handler om at føle sin hjemme og føle sig tryg (Yuval-Davis 2006).

Hovedparten af Yuval-Davis' arbejde har været rettet mod 'politics of belonging', som hun betegner som "the dirty work of boundary maintenance" (Yuval-Davis 2007:563). I bogen Gender and Nation har Yuval-Davis en række eksempler på, hvordan skabelse af identitetspolitikker er blevet brugt til at ekskludere bestemte grupper samt, hvordan køn har været med til at definere nationen som et forestillet fællesskab, f.eks. gennem argumenter om oprindelse, slægtskab, kultur og religion (Yuval-Davis 1997).

Den såkaldte 'cricket-test' er et gennemgående eksempel i flere af Yuval-Davis' arbejder. Metaforen fra sportsverdenen bruges til at illustrere forskellen mellem et medborgerskab, der anerkender forskellighed over for 'politics of belonging', der ekskluderer bestemte medborgere. Crickettesten blev formuleret af den konservative minister Norman Tebbit, som mente, at man kunne teste, hvilke minoritetsgrupper, der var ' $x g t e$ ' britiske (og dermed hørte til det britiske fællesskab), når et britisk cricket hold spillede mod et hold fra oprindelseslandet. Hvis man holdt med oprindelseslan- det, var det et udtryk for, at man stadig ikke var et fuldgyldigt medlem af det britiske fællesskab (Yuval-Davis 2006:210).

Tankegangen om forestillede nationale fællesskaber er på det seneste blevet fulgt op af en anden fremtrædende feminist, nemlig Judith Butler i bogen Who Sings the Nation State? (Butler \& Spivak 2007). I sin tilgang til nationale fællesskaber bygger Butler på tankegangen om bipolaritet, som vi kender fra hendes teorier om køn og seksualitet (Butler 1990, 1993). Hendes udgangspunkt er 'belonging', og hun argumenterer for, at der i konstruktionen af, hvem der 'hører til' nationalstaten samtidig sker en konstruktion af hvem, der ikke 'hører til'. Sådanne biopolariteter bidrager til at skabe såkaldte mono-lingvistiske fællesskaber, hvilket Butler eksemplificerer med den amerikanske nationalsang The Star-Spangled Banner. Der findes mange eksempler på manipulationer med denne nationalhymne. F.eks. på Woodstock-festivalen i 1969, hvor Jimi Hendrix fik sangen til at lyde som en torden af bomber og missiler over Vietnam. Butlers eksempel er knyttet til en nyere furore om nationalsangen. I 2006 blev den i spansk oversættelse Nuestro Hymno - brugt af illegale latinamerikanske immigranter i forbindelse med omfattende demonstrationer i en række amerikanske storbyer, ligesom den blev spillet på en række latinamerikanske radiokanaler. Dette førte til udtalelser fra præsident Bush om, at nationalsangen skulle synges på engelsk.

If, as Bush claimed at the time, the national anthem can only be sung in English, then the nation is clearly restricted to a linguistic majority, and language becomes one way of asserting critical control over who belongs and who does not (Butler \& Spivak, 2006:59).

Butlers pointe er, at sådanne markeringer bidrager til at stadfæeste, at nationen er begrænset til én lingvistisk majoritet. På den anden side betyder det faktum, at presiden- 
ten i det hele taget italesætter spørgsmålet om, hvorvidt nationalsangen kan synges på andre sprog, at den allerede bliver det, eller at det allerede er ude af kontrol. Butler inddrager her sit begreb om performativitet, dvs. hvordan diskurser materialiseres gennem performativer og gentagne handlinger (Butler 1990). I forhold til brugen af Nyestro Hymno taler Butler om 'performative contradiction', som eksempelvis kan være moddiskurser, der kan skabes, når nationalsangen synges på andre sprog 'på gaden'. Dette udfordrer og forandrer ikke kun nationens sprog, men også det offentlige rum (Butler \& Spivak 2007).

\section{'DANSKHED' SOM FORESTILLET FÆLLESSKAB}

Som nævnt tidligere er spørgsmålet om 'danskhed' en dominerende diskurs i offentligheden i disse år. Et aktuelt eksempel på, hvordan denne diskurs bruges som markør er en annonce fra Dansk Folkeparti, som i maj 2008 blev bragt i de fleste større aviser. Annoncen viser en burkaklædt dommer, og den har til formål at markere afstand til brug af hovedbeklædning i danske retssale. Annoncen har været omdiskuteret og kritiseret for dens manipulerende budskab, fordi den kobler debatten om dommeres ret til at bruge hovedbeklædning med at være klædt i burka. Jeg vil her ikke gå ind $\mathrm{i}$ en længere analyse af annoncen, men nøjes med at forholde mig til ét udsagn, som mest direkte forholder sig til spørgsmålet om nationalisme og forestillede fællesskaber - nemlig sætningen nederst i annoncen: $G i$ ' os Danmark tilbage. ${ }^{3}$

For det første kan man spørge, hvem 'os' dækker over, og hvem defineres som 'de andre'? Det fremgår tydeligt af teksten ovenfor, at det er dem, man kalder 'islamister', dem der symboliserer kvinders underkastelse og dem, der accepterer tyranni. Med denne negative sprogbrug făr annoncen konstrueret alle muslimer som stående udenfor 'det at være dansk'. For det andet ligger der i annoncen en markant hentydning til, at der er nogen, der har taget Danmark fra nogen andre. Set i forhold til, hvem der konstrueres som 'de andre', kan der ikke herske tvivl om, hvem det er.

Herudover knytter sætningen mere indirekte an til to andre diskurser. For det første en 'klassisk fæedrelandsdiskurs', der er baseret på frygten for, at der er nogen, der vil tage nationen og fædrelandet fra os. Dette er i tråd med en af Benedict Andersons seneste pointer, hvor han fremhæver, at frygten ikke længere er, at nationen skal blive invaderet 'udefra' af nabolande. Frygten i dag kommer 'indefra' fra grupper i samfundet, som forestilles at ville fratage nationen dens særtræk (Anderson 2008). Den anden diskurs knytter sig til moderne rap-musik og den afdøde Natasjas sang Giv mig Danmark tilbage. Denne sang indeholder bl.a. en protest mod Dansk Folkeparti. Det er vanskeligt at sige, hvor bevidst Dansk Folkeparti har tvistet Natasjas populære sang - om det er et forsøg på at etablere en moddiskurs eller at udnytte et kendt slogan politisk.

Jeg vil nu gå over til at se på, hvordan tilhørsforhold konstrueres som en del af hverdagens fortællinger $i$ et boligområde $i$ Aalborg.

\section{INTERLOC-PROJEKTET}

INTERLOC-projektet - Køn, klasse og etnicitet. Intersektionalitet og lokalt medborgerskab er udviklet sammen med Sune Qvortrup Jensen og i tæt samarbejde med Anette Borchorst og Birte Siim. ${ }^{4}$ Projektet er forankret i en bestemt lokalitet, nemlig Aal-

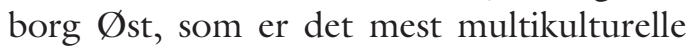
område i Aalborg. Det er dog værd at fremhæve, at Aalborg med 7 pct. og Aalborg Øst med 18 pct. indvandrere eller efterkommere efter indvandrere ligger betydelig under flere andre større danske byer. F.eks. er 20 pct. af befolkningen i Københavns kommune af anden etnisk oprindelse end dansk. På Nørrebro er det 28 pct. der har 
en ikke etnisk dansk baggrund (Skjøtt-Larsen 2008).

Projektets formål er at undersøge, hvordan forestillinger om medborgerskab og multikulturalisme kommer til udtryk i 'almindelige menneskers' hverdag og kulturelle praksis. Det er opbygget omkring en intersektionalitet-tilgang, idet samspillet mellem køn, klasse, etnicitet og andre forskelssættende kategorier står centralt. Vi lægger vægt på, at køn, klasse og etnicitet både skal ses som sociale kategorier og som identiteter (Christensen \& Siim 2006, Jensen 2006, Faber 2008). Dette er bl.a. inspireret af den engelske sociolog Beverley Skeggs, der ligesom Bourdieu understreger, at klasse både skal ses som sociale positioner og som klassifikationssystemer, der har betydning for, hvem vi identificerer os med.

Sociale positioner handler om objektive betingelser og fordeling af ressourcer. Dvs. hvor stor adgang man har til kulturel, økonomisk, social og symbolsk kapital. Identiteter ser Skeggs som kategorier og klassifikationssystemer, der fungerer som symbolske grænsedragninger i forhold til, hvem man vil ligne og ikke ligne - hvem man føler et tilhørsforhold til, og hvem man markerer afstand til. Det betyder, at klasse (såvel som køn og etnicitet) både handler om materielle eksistensvilkår og de mangfoldige relationer, vi har til hinanden (Skeggs 1997, 2004).

Skeggs har udviklet sin teoretiske forståelse gennem omfattende empiriske studier af unge engelske arbejderkvinder, og hendes grundlrggende pointe er, at disse kvinder har en klar bevidsthed om deres lave position i samfundet, men at de på samme tid hele tiden forsøger at forlade den.

To af Skeggs begreber er særlig relevante for vores analyser. Det ene er respektabilitet, som er en vigtig markør for de unge kvinder. At være respektabel er en måde at forbinde sig med dominerende normer, men også at markere grænser i forhold til det, man opfatter som mindre respekterede grupper. Det andet er sammenhængen mellem identitet og ikke-identitet, hvor Skeggs pointe er, at hvis man skal lokalisere identiteter er det mindst lige så vigtig at se på ikke-identifikation, dvs. hvem der lægges afstand til; hvem man ikke vil ligne; hvem man markere ikke-tilhørsforhold til.

Pointen er således, at kategorierne klasse, køn og etnicitet ikke kun er forankrede i objektive og strukturelle forhold. Kategorierne er også i spil som centrale og aktive markører i det levede liv, dvs. i de daglige relationer, hvor vi møder hinanden, og det er precis de processer, vi forsøger at indkredse i Aalborg Øst. Dette sker bl.a. gennem narrative fortællinger om tilhørsforhold og identitet i forhold til at belyse samspillet mellem lokalitet, etnicitet, køn og klasse, hvilket jeg nu vil give nogle eksempler gennem tre stemmer fra bydelen. ${ }^{5}$

\section{FORTÆLLINGER OM LOKALT TILHØRSFORHOLD}

Grethe er i begyndelsen af 60'erne. Hun er butiksuddannet, men nu på efterløn, ligesom sin mand. De har to voksne børn og et par børnebørn. De flyttede fra en anden jysk provinsby til Aalborg i 1960'erne; i 1970'erne til Aalborg Øst - først til et af gårdhusene og siden til et af villakvarterne.

Samira er 40 år; palæstinenser, født og opvokset i Syrien, som forældrene flygtede til i 1948 efter den israelske besættelse. Samira er uddannet kontorassistent og lxser på seminariet. Hun er muslim, har været gift to gange, men bor nu alene med sine tre børn. Samira har boet i Danmark i 14 år - de seneste 11 år i den samme lejlighed i Aalborg Øst.

Peter er i begyndelsen af 50'erne. Han er født og opvokset i Aalborg. Faglært arbejder, gift og har to voksne børn. Peter har altid boet i Aalborg - først i Vestbyen, en kort tid i Vejgård og siden gennem ca. 20 år i et af villakvartererne i Aalborg Øst.

I det følgende vil jeg belyse hvilke tilhørsforhold og sociale grænsedragninger, 
der kan lokaliseres i deres fortællinger først om Hasseris versus Aalborg Øst og dernæst om at bo i Aalborg Øst.

Aalborg Øst og Hasseris udgør modpolerne mellem Aalborgs bydele. Undersøgelser viser, at der er meget store sociale forskelle mellem de to områder. F.eks. ligger Hasseris langt over gennemsnittet af de højeste indkomster i Aalborg, mens Aalborg Øst ligger langt under. Men samtidig er det også tydeligt, at disse forskelle forstærkes gennem de symbolske betydninger, de to boligområder har (se uddybende Skjøtt-Larsen 2008, Christensen 2008).

Peter hører dog ikke til dem, der mener, der er den store forskel på Aalborg Øst og Hasseris. Tværtimod fremhæver han Hasseris som et af de områder, der ligner Aalborg Øst, fordi der også er mange parcelhusområder. For ham at se er der tale om samme type kvarterer og samme type mennesker, der bor i Hasseris, som hvor han bor. Sådan har Grethe det ikke:

"Nu har vi nogle venner, der kommer inde fra Hasseris. De kan slet ikke forstå, vi vil bo herude i Aalborg Øst. De vil gerne have os til Hasseris, der synes de, vi passer bedre. Det er sådan, at når de kommer kørende hertil og kigger på kvarteret, så ser det ikke pænt ud. Jeg ved ikke, om du lagde mærke til, da du kom kørende (...) Men prøv at lægge mærke til det hus her og det der”.

Men selv kunne hun ikke tænke sig at bo i Hasseris. Hun siger videre:

“Altså, der er nogle, der gerne vil bo i Hasseris for at sige, de bor i Hasseris. Det vil jeg ikke (...) Selv om jeg kunne flytte gratis eller bytte, så ville jeg ikke bo ude i Hasseris. Og det har nok noget at gøre med, da jeg kom til byen og arbejdede i forretning. Alle de fine fruer ude fra Hasseris, der kom ind i forretningen. For det første var de meget besværlige og troede, de skulle have en anden behandling end andre. Og så skulle de altid skrives. De betalte ikke. Dem kunne man sende regning til i laaang tid! Det var både fru direktør et og andet. Så har man sådan en antipati imod dem der. Der sagde vi 'Haasseris' [udtalt med 'fint' a] (...) Så derfor har jeg sagt, jeg vil aldrig bo i Hasseris”.

Her ser vi to forskellige opfattelser af Aalborg $\emptyset_{\text {st }}$ i forhold til Hasseris. Hvor Peter lægger vægt på, at han - som dem i Hasseris - bor i parcelhus, er Grethe mere kritisk. Selv kunne hun ikke tænke sig at bo i Hasseris, fordi hun forbinder bydelen med overklassekvinder, som hun distancerer sig fra. Hun er dog godt klar over, at Hasseris repræsenterer en højere social status, hvilket vennerne bekræfter hende i. Hun lægger i stedet vægt på, at også Aalborg Øst skal være et respektabelt kvarter, så det ser pænt ud, når de får besøg. Vi ser, hvordan klasse og køn både er markører og krydser hinanden i måden, hvorpå Grethe omtaler de fine fruer og $\mathrm{i}$ den positionering, som hun oplever fra Hasseris-vennernes side.

Spørgsmålet om social distance og respektabilitet er også en gennemgående træk, når Grethe fortæller om interne forskelle $\mathrm{i}$ det villakvarter, hvor hun bor i Aalborg Øst. Hun fortæller, at der er flyttet mange udlændinge ind, og det er fint for hende, hvis bare de holder hus og have ordentligt. "Jeg kan ikke forstå, hvad de vil med et hus, når de ikke passer haven og sådan noget. Det er deres kultur", siger hun.

Grethe mener, at haver skal holdes efter bestemte normer. Hun synes, det ser frygtelig ud, når nogle kinesere, der bor ved siden af dem, hænger en masse glimmerværk op udendørs. Hun synes ikke, det er folks private sag, hvordan de holder haven, og hvis ikke man gør det ordentligt, så kan man efter hendes mening lige så godt bo i en lejlighed. På spørgsmålet om der er forskel på dem, der bor i villaerne og dem, der bor oppe i blokkene, siger hun:

“Altså dem herovre de kunne lige så godt bo oppe i blokkene. Vi har de værste genboer 
(...) De er danskere, pæredanske. Men de råber og skriger. Man kan sidde herinde i stuen og høre, hvordan hun råber og skriger, selvom døre og vinduer er lukkede, så kan man høre det ude i køkkenet. Neeeej for et sprog."

Her markeres to former for social distance, som begge handler om respektabilitet og spørgsmålet om at leve op til at holde sin have og udvise passende adfærd i forhold til at bo i parcelhus. Gør man ikke det, kan man lige så godt bo i blokkene. Dermed markeres også en tydelige skillelinje mellem dem, der bor i lejlighed, og dem, der bor i parcelhus. Det er den primære markør. Her er det ikke klasse, der er omdrejningspunktet, men etnicitet. Men det sker på den måde, at der også er etniske danskere, der ikke kan leve op til standarden for respektabel adfærd i parcelhusområdet. Indirekte kommer der dog også stereotype opfattelser af etniske minoriteter frem, når kulturen gives som forklaring på forskellige standarder for, om man skal have blomster eller glimtende lygter i haven.

Samira er rigtig glad for sin stuelejlighed med have og 4 værelser, som hun har boet $\mathrm{i}$ gennem 11 år. Hun synes godt om området, hvis det ikke var for hundene og de alt for hurtige knallerter. Som Grethe har Samira dog også naboer, som hun er træt af. De spiller musik hele tiden, også om natten. Men hun tør ikke sige noget til dem, da hun er hun bange for, at de vil slå hende. Samira er glad for nabofællesskabet, hvor hun bor. De er gode til at tage hensyn til hinanden, selvom de er forskellige, og det finder hun afgørende for et godt fællesskab:

"De forskellige mennesker er forskellige. Uanset om vi er arabere eller vi er herfra, så er vi meget forskellige. Selv om vi er den samme familie er vi alligevel forskellige (...) Mine værdier er ikke ligesom min nabos værdier. Selv om vi er arabere og fra Syrien er vi helt forskellige indbyrdes."
Til gengæld er Samira kritisk over for andre områder i Aalborg Øst:

“Men dem på Fyrkildevej og Ravnkildevej. De er helt anderledes. På Ravnkildevej er det unge indvandrere, tror jeg. Der står altid om dem [i avisen]. Jeg ved ikke, hvad jeg skal mene om det. Men det er virkeligheden. For forældrene dér, de passer ikke godt på deres børn. De har måske ikke tid til dem.”

I det hele taget lægger Samira vægt på forældrenes ansvar i forhold til børnene, og hun lægger mærke til, hvordan de opdrager deres børn. Hun fortæller, at hun bliver sur og ked af det, hvis hun møder arabere, som ikke kan finde ud af at være ordentlige forxldre.

Der kommer forskellige perspektiver frem i interviewet med Samira. Det afgørende for hende er ikke etageboliger versus villaer, men i stedet interne positioneringer mellem forskellige dele af kvarteret. Hun lægger vægt på tillid og tryghed. Hun bliver skræmt, når nogen råber, og hun er bange for knallertkørsel og hunde. Endelig fremhæver Samira, at der skal være plads til forskellighed - både mellem og inden for etniske grupper. Det ses f.eks., når hun peger på moderskab og ansvarligt forældreskab som en vigtig markør i forhold til respektabilitet, men samtidig også lægger afstand til de familier med minoritetsbaggrund, som ikke lever op til hendes normer om ansvarligt forældreskab.

Ser vi til slut på Peter, så har han en høj grad af tilhørsforhold til det villakvarter, hvor han bor i Aalborg Øst. Han har meget kontakt til naboer, de mødes i dagligdagen, holder fester og er med i grundejerforeningen. Til gengxld forholder Peter sig stort set ikke til de andre områder i Aalborg Øst:

“(...) Ja, men hvis jeg boede der, så tror jeg også, jeg kunne acceptere det på en eller anden måde. Men man skulle i hvert fald lære det at kende. (...) Der bor så mange blandede mennesker (...) Vi kommer stort set aldrig 
i de blokke. (...) Jeg har ikke noget forhold til det."

Vi ser her en ikke-identifikation med de dele af Aalborg $\emptyset_{\text {st }}$, som ligger uden for det parcelhuskvarter, som Peter bor i. På sin vis har han tidligere i interviewet udtrykt tolerance i forhold til etniske minoriteter. Men han vil helst ikke møde dem og forholder sig ikke til dem som en del af sin hverdag. Peter lægger indirekte afstand til det at bo med så mange blandede mennesker - i modsætning til Samira, der fremhæver det som en vigtig værdi i hverdagens sociale relationer.

\section{KONKLUSION}

De symbolske grænsedragninger handler for det første om markeringer, som bygger på sammenligninger mellem Aalborg Øst og andre bydele - først og fremmest Hasseris. Der er her tale om en klar markør, som er forankret i sociale forskelle, men bliver forstærket gennem symbolske markeringer. For de mennesker, der bor i Aalborg Øst, ser denne grænsedragning i forhold til Hasseris ud til at virke forskelligt. Mens nogle gerne vil sammenlignes med Hasseris og udtrykker, at såvel huse som mennesker ligner Hasseris, markerer andre en klar distance. For det andet ser vi interne grensedragninger i Aalborg Øst, som krydser hinanden på overlappende, men også modsætningsfyldte måder. Det drejer sig om:

- villakvarterer versus etagebyggeri, - interne markeringer i etagebyggerierne, f.eks. mellem forskellige veje, - interne markeringer i villakvarteret, f.eks. $\mathrm{i}$ forhold til pasning af haver.

Hertil kommer positioneringer i forhold til, hvem der lever op til respektabel adfærd. Disse kan være bundet til normer om at være gode forældre samt til, hvem der i det hele taget udviser passende adfærd. Endelig fremhæves spørgsmålet om tryghed og sik- kerhed som vigtige parametre i forhold til, hvor man færdes i området.

Et vigtigt spørgsmål er, om der er tegn på, at 'os/dem'-tænkningen om majoritet og minoritet brydes? Svaret herpå er dobbelt. På den ene side brydes de stereotype opfattelser af, at sådan er etniske danskere, og sådan er etniske minoriteter. Der er også etniske danskere, der råber og skriger af hinanden, og som ikke passer hus og have. Ligeledes er der etniske minoriteter, der er gode og kompetente forældre. På den anden side kan vi også se, at fordomme og stereotype opfattelse af 'de andre' er med til at påvirke de symbolske grænsedragninger, når der f.eks. henvises til 'deres' kultur eller markeres en ikke-identifikation til grupper, som bor uden for ens eget område. De værdier om 'forskellighed', som den palæstinensiske kvinde Samira, giver udtryk for, genfinder jeg ikke eksplicit i interviewet med de to etniske danskere.

Et andet spørgsmål er, hvordan dette glimt af hverdagslivet og lokale fællesskaber $i$ et boligområde hænger sammen med medborgerskab og tilhørsforhold. Jeg er som nævnt gået ned i hverdagslivet og de sociale interaktioner $i$ et bestemt lokalt område med fokus på det, som jeg kalder 'levet liv'. Der kan synes langt fra disse daglige relationer i hverdagen til spørgsmålet om forestillede fællesskaber om nationalisme, religion, danskhed. Imidlertid er det tydeligt, at de kulturelle grænsedragninger ikke kommer ud af den blå luft. Markeringerne fungerer som underliggende forestillinger, hvor køn, klasse og etnicitet spiller sammen og præger de sociale relationer $\mathrm{i}$ hverdagen.

Der er ingen tvivl om, at symbolske grænsedragninger virker hæmmende på udviklingen af sociale fællesskaber og følelser af tilhørsforhold. Her bør signaler 'fra oven' - fra det politiske system og de politiske partier - være med til at styrke åbenhed, tolerance og retten til at være forskellige. Manipulerende og fjendtlige annoncer, der lægger bestemte grupper for had, kan 
kun spænde ben for dette. I den sammenhæng har vi som kønsforskere, efter min mening, en særlig forpligtigelse til at være opmærksomme på misvisende brug af argumenter om ligestilling mellem kønnene.

\section{NoTER}

1. Jeg bruger primært den danske betegnelse tilhørsforhold, hvilket er en oversættelse af det engelske begreb 'belonging'. Imidlertid er der områder, hvor 'tilhørsforhold' ikke er dækkende for den bredere engelske betegnelse. Derfor er der steder i teksten, hvor jeg har valgt at fastholde 'belonging'. 2. Kønsforskere har kritiseret Benedict Anderson for at overse køn og etnicitet i teorier om nationsog nationalitetsdannelser (se fx Yuval-Davis 1997, Andreassen 2006).

3. Annoncen kan ses på Dansk Folkepartis hjemmeside/annoncer http://www.danskfolkeparti.dk/pictures_org/DF -sloer-annonce4.pdf

4. I projektet deltager adjunkt Sune Qvortrup Jensen, post.doc Stine Thidemann Faber og videnskabelig assistent Jakob Skjøtt-Larsen samt undertegnede, som er projektleder. Projektet er finansieret af Forskningsrådet for Samfund og Erhverv fra 2007-2010. Dele af projektet bygger det videre på data fra COMPAS-projektet, som professor Annick Prieur er leder af, se evt. uddybende http://www.socsci.auc.dk/compas/index.htm 5. Interviewene er foretaget $i$ begyndelsen af 2008. Der er tale om semi-strukturerede interviews som oftest foretaget i interviewpersonernes hjem. Sune Qvortrup Jensen har foretaget interviewet med Samira, og jeg har foretaget de to andre. Interviewpersonernes identitet er sløret.

\section{LITTERATUR}

- Anderson, Benedict (2001): Forestillede fallesskaber. Refleksioner over nationalismens oprindelse og udbredelse. Roskilde Universitetsforlag, Gylling [opr. 1983/rev. 1991].

- Anderson, Benedict (2008): Nationalstaten er ikke under afvikling - ikke lige foreløbig, Information 19-20.04.08.

- Andreassen, Rikke (2007): Der er et yndigt land. Medier, minoriteter og danskhed. Tiderne Skifter, København.
- Andreassen, Rikke (2006): Intersektionalitet i voldtægtsnarrativer, i Kvinder, Kon og Forskning, nr. 2-3 2008.

- Andreassen, Rikke (2005): The Mass Media's Construction of Gender, Race, Sexuality and Nationality. An Analysis of the Danish News Media's Communication about Visible Minorities from 1971-2004. Department of History, University of Toronto.

- Bundesen, Peter, Lars Skov Henriksen \& Anja Jørgensen (2001): Filantropi, selvhjalp og interesseorganisering. Frivillige organisationer $i$ dansh socialpolitik 1949-1990erne. Odense Universitetsforlag, Odense.

- Butler, Judith \& Gaytri C. Spivak (2007): Who sings the Nation-State? Language, politics, belonging. Seagull Books, New York.

- Butler, Judith (1990): Gender Trouble - Feminism and the Subversion of Identity. Rothledge, Chapman \& Hall, New York.

- Butler, Judith (1993): Bodies that matter. On the discursive limits of sex. Routledge, London.

- Castells, Manuel (1998): The Information Age: Economy, Society and Culture. Vol. II: The Power of Identity. Blackwell Publ., Cambridge.

- Christensen, Ann-Dorte (2008): Forandring, fallesskab og identitet. Tiltradelsesforelasning den 4. juni, 2008. Sociologiske Arbejdspapirer nr. 23.

. Christensen, Ann-Dorte \& Birte Siim (2006): Fra køn til diversitet - intersektionalitet i en dansk/nordisk kontekst, i Kvinder, Køn og Forskning, nr. 2-3 2006.

- Bundesen Peter, Lars Skov Henriksen \& Anja Jørgensen (2001): Filantropi, selvhjalp og interesseorganisering. Frivillige organisationer $i$ dansk socialpolitik 1949-1990erne. Odense Universitetsforlag, Odense.

- Elg, Camilla (2005): Set og overset. Unge kvinder med indvandrerbaggrund $i$ Danmark, Ph.d.-afhandling, Akademiet for Migrationsstudier i Danmark, Aalborg Universitet.

- Faber, Stine Thidemann (2008): På jagt efter klasse. Ph.d.-afhandling, Institut for Sociologi, Sociale Forhold og Organisation, Aalborg Universitet.

- Gullestad, Marianne (2006): Plausible Prejudice: Everyday Practices and Social Images of Nation, Culture and Race. Universitetsforlaget, Oslo. - Gundelach, Peter (1988): Sociale bevagelser og samfundsandringer. Forlaget Politica, Århus.

- Jensen, Sune Qvortrup (2006): Hvordan analysere sociale differentieringer?, i Kvinder, Køn og Forskning, nr. 2-3 2008.

· Jørgensen Anja \& Anne-Kirstine Mølholt (2007): 
Betingelser for fellesskab. Om sindslidende i boligområder. Servicestyrelsen, København.

- Prieur, Annick (2004): Balansekunstnere. Betydningen av innvandrerbakgrunn i Norge. Pax A/S, Oslo.

- Savage, Mike, Gaynor Bagnall \& Brian Longhurst (2005): Globalization \& Belonging. Sage Publications, Gatedshead.

- Siim, Birte (2007): The Challenge of Recognizing Diversity from the Perspective of Gender Equlity: Dilemmes in Danish Citizenship, ni Critical Review of International, Social and Political Philosophy, Special Issue, vol. 10, no 4 2007, pp. 491-511.

- Skeggs, Beverly (1997): Formations of Class and Gender. Sage Publications, London.

- Skeggs, Berverly (2004): Class, Self, Culture.

Routledge, London and New York.

- Skjøtt-Larsen, Jakob (2008): En fysisk, en social og en mental del af byen, Sociologiske Arbejdspapirer, nr. 24 (under udgivelse).

- Staunæs, Dorthe (2003): Where have all the subjects gone? Bringing together the concepts of intersectionality and subjectification, i NORA, vol. 11/2 2003, pp. 101-110.

- Torpe, Lars \& Torben K.Kjeldgaard (2003): Foreningssamfundets sociale kapital. Danske foreninger $i$ et europeisk perspektiv. Magtudredningen, Århus. - Tilly, Charles (2002). Stories, Identities and Political Change. Rowman \& Littlefield Publ. Inc., Lanham.

- Yuval-Davis, Nira (2007): Intersectionality, Citizenship and Contemporary Politics of Belonging, in Critical Review of International, Social and Political Philosophy, Special Issue, vol. 10, no 42007 , pp. 561-574.

- Yuval-Davis, Nira (2006): Belonging and the politics of belonging, in Pattern of Prejudice, vol. 40, no. 3 2006, pp. 197-214.

- Yuval-Davis (1997): Gender and Nation. Sage

Publications, London.
SUMMARY

Nation and local belonging

gender, class, and ethnicity as social distinctions

Who is included and who is excluded are essential questions in modern society and belonging has become a strong factor in making distinctions between 'us' and 'them' in public life as well as in social relations in every day life. This essay is twofold: The first part presents and discusses the notion of belonging based on primarily contributions on nation-building as imaged communities from two feminists Nira Yuval-Davis and Judith Butler. Belonging as an excluding boundary is subsequently illustrated by an example from the Danish media. The second part of the article is based on The INTERLOC project - Gender, Class and Ethnicity. Intersectionality and Local Citizenship where narratives on local belonging and identification are analyzed in relation to the intersection between locality, ethnicity, class, and gender.

Ann-Dorte Christensen

Professor ved Institut for Sociologi,

Socialt Arbejde og Organisation

Aalborg Universitet. 